\title{
KARAKTERISASI KEJU DANGKE MENGGUNAKAN ENZIM PAPAIN KOMERSIAL DAN PERUBAHAN FISIK SELAMA PENYIMPANAN
}

\author{
[Characterization of Dangke Cheese Made Using Commercial Papain \\ and Physical Changes During Storage]
}

\author{
Nurul IImi Musra ${ }^{1) \star}$, Serdanawati Yasni ${ }^{2)}$, dan Elvira Syamsir ${ }^{2)}$ \\ 1) Progam Studi IImu Pangan, Sekolah Pascasarjana, IPB University, Bogor \\ ${ }^{2}$ Departemen IImu dan Teknologi Pangan, Fakultas Teknologi Pertanian, IPB University, Bogor
}

Diterima 3 Februari 2020 / Disetujui 23 Maret 2021

\begin{abstract}
Dangke is one of the traditional cheeses made from buffalo milk or cow's milk from Enrekang, South Sulawesi,. This research aimed to obtain dangke cheese through a process using commercial papain as the curdling agent and to determine the best products based on the analysis of physical properties of the raw materials and the dangke. The dangke making was conducted using several concentrations of the commercial papain (0.2-5\%). Based on the texture, yield and non-bitter taste intensity, the best dangke was obtained using 1, 3, and 5\% commercial papain. Dangke made using 1, 3, and 5\% commercial papain resulted in yields of 18,17 , and $18 \%$, respectively with compact texture and non-bitter taste. At room temperature storage $\left( \pm 30^{\circ} \mathrm{C}\right)$, the dangke had shelf life of less than 24 hours, while at low temperature storage $\left( \pm 4^{\circ} \mathrm{C}\right)$, dangke could last for four days.
\end{abstract}

Keywords: commercial papain, dangke, storage

\begin{abstract}
ABSTRAK
Dangke merupakan salah satu keju tradisional dari Enrekang, Sulawesi Selatan yang terbuat dari susu kerbau atau susu sapi. Penelitian ini bertujuan mendapatkan keju dangke melalui pengolahan yang menggunakan enzim papain komersial sebagai penggumpal susu, dan menentukan produk terbaik berdasarkan analisis sifat fisik dari bahan baku dan dangke. Penelitian ini dilakukan dengan menggunakan beberapa konsentrasi enzim papain komersial (0,2-5\%). Berdasarkan hasil penelitian dengan parameter tekstur, rendemen dan intensitas rasa pahit, diperoleh konsentrasi terbaik penggunaan enzim papain komersial adalah 1, 3, dan 5\% (w/v) dengan rendemen berturut-turut 18, 17, dan $18 \%$ dengan tekstur kompak dan rasa yang tidak pahit. Hasil analisis fisik menunjukkan bahwa pada penyimpanan suhu ruang $\left( \pm 30^{\circ} \mathrm{C}\right)$, dangke hanya bertahan kurang dari 24 jam, sedangkan pada penyimpanan suhu dingin $\left( \pm 4^{\circ} \mathrm{C}\right)$, dangke awet selama empat hari.
\end{abstract}

Kata kunci: dangke, papain komersial, penyimpanan

\section{PENDAHULUAN}

Dangke merupakan produk keju tradisional dari Kabupaten Enrekang, Sulawesi Selatan (Fatma et al., 2012), dengan karakteristik berbentuk oval, tekstur kompak dan kenyal, beraroma susu yang kuat dan memiliki citarasa gurih. Dangke dapat berwarna putih kekuningan jika diolah menggunakan susu kerbau (Suryani dan Niswah, 2015). Umur simpan dangke relatif singkat karena kadar air tinggi, yaitu sekitar 49,3-62,4\% (Hatta et al., 2013). Proses pengolahan dangke umumnya masih di-

*Penulis Korespondensi:

E-mail: ilmi_musra@apps.ipb.ac.id lakukan secara konvensional, melalui pemanasan susu segar yang ditambahkan getah pepaya sebagai enzim penggumpal (Hatta et al., 2014), sehingga terbentuk 2 fase, yaitu curd (padatan) dan whey (cairan).

Keju merupakan hasil penggumpalan susu dengan memanfaatkan enzim sebagai koagulan. Umumnya, proses pembuatan keju memanfaatkan enzim rennet yang bersifat proteolitik dan dapat menggumpalkan susu pada proses awal pembuatan kejun, akan tetapi rennet tersedia dalam jumlah terbatas (Hutagalung et al., 2017). Pembuatan dangke dan keju segar memiliki perbedaan pada penggunaan enzim untuk penggumpalan (koagulasi). Pada produk dangke digunakan enzim papain yang 
berasal dari getah pepaya, sedangkan pada keju segar umumnya menggunakan rennet dan atau asam yang dihasilkan dari kultur bakteri atau sumber lain seperti jus lemon (Malaka et al., 2015).

Ditinjau dari proses pengolahannya dan karakteristiknya, dangke termasuk dalam golongan keju segar (fresh cheese) tanpa pemeraman. Keju segar merupakan produk susu yang memiliki $\mathrm{pH}$ mendekati netral, kadar air dan aktivitas air tinggi sehingga memungkinkan pertumbuhan patogen dan mikroorganisme pembusuk yang dapat mengurangi umur simpannya (Evert-Arriagada et al., 2013). Keju segar memiliki kadar air sekitar $46-57 \%$, kadar protein 15 $21 \%$, kadar lemak $20-29 \%$, kadar garam dari $1-3 \%$ dan $\mathrm{pH}$ pada kisaran 5,3-6,5. Keju segar dibuat dari susu murni dan memiliki rasa yang mirip dengan susu segar, walaupun kadang-kadang sedikit asin (González et al., 2018).

Produksi dangke yang menggunakan getah pepaya masih menghasilkan rasa pahit meskipun pada konsentrasi rendah. Getah pepaya yang ideal digunakan adalah dari buah pepaya berumur 2,5-3 bulan (Sulmiyati dan Said, 2018). Penambahan getah pepaya pada keju segar dengan konsentrasi $0,125 \%$ menghasilkan rasa pahit, sehingga penggunaan getah pepaya dapat digantikan dengan enzim papain komersial (Sulistyo et al., 2018). Enzim papain komersial yang digunakan adalah papain komersial PAYA yang memiliki aktivitas proteolitik enzim sebesar $0,0072 \mathrm{mg} / \mathrm{mL}$ dengan aktivitas spesifik rata-rata $0,0447 \mathrm{U} / \mathrm{mg}$.menit. Selain efektif digunakan untuk hidrolisis, enzim papain komersial juga mudah didapatkan dengan harga yang ekonomis (Sumarlan et al., 2017). Penelitian ini bermaksud mendapatkan konsentrasi enzim papain komersial terbaik pada pembuatan dangke sebagai alternatif menyamarkan rasa pahit serta melihat perubahan fisik selama penyimpanan suhu dingin.

\section{BAHAN DAN METODE}

\section{Bahan}

Penelitian ini menggunakan bahan-bahan antara lain susu sapi segar tanpa pasteurisasi yang diperoleh dari Fakultas Peternakan IPB University, enzim papain komersial (PAYA, Enzyme Development Enterprise) yang diperoleh dari pasar swalayan.

\section{Analisis proksimat (AOAC, 2012)}

Analisis proksimat yang digunakan untuk karakterisasi susu segar adalah kadar air, kadar protein, kadar abu dan kadar lemak.
Penentuan konsentrasi enzim papain komersial untuk pembuatan dangke (Fatma, 2012 dengan modifikasi)

Tujuan penentuan konsentrasi enzim papain komersial adalah untuk mendapatkan konsentrasi enzim terbaik yang digunakan untuk membuat dangke. Proses pembuatan dangke mengacu pada Fatma (2012) dengan modifikasi diawali dengan disiapkan susu sapi segar yang belum dipasteurisasi. Susu segar sebanyak $1000 \mathrm{~mL}$ dipanaskan hingga mencapai suhu $70^{\circ} \mathrm{C}$. Konsentrasi enzim papain komersial yang digunakan adalah 0,2 ; 0,$4 ; 0,6 ; 0,8 ; 1 ; 3$; dan $5 \%(\mathrm{w} / \mathrm{v})$, kemudian ditambahkan dalam susu ketika mencapai suhu $70^{\circ} \mathrm{C}$ dan dibiarkan hingga membentuk gumpalan. Setelah terbentuk dua fase, yaitu curd yang memadat dan cairan berupa whey, selanjutnya curd disaring untuk dipisahkan dari whey. Curd yang terbentuk dimasukkan ke dalam wadah plastik berukuran $8,6 \times 8,6 \times 3,8 \mathrm{~cm}$ sambil ditekan-tekan dengan menggunakan tangan agar curd memadat dan cairannya keluar. Parameter yang diamati adalah rendemen, tekstur, dan rasa dangke yang dihasilkan.

\section{Stabilitas dangke selama penyimpanan}

Dangke dengan konsentrasi enzim papain komersial terpilih selanjutnya dilakukan penyimpanan pada suhu ruang $\pm 30^{\circ} \mathrm{C}$ dan suhu dingin $\pm 4^{\circ} \mathrm{C}$. Dangke dimasukkan ke dalam wadah plastik dan ditutup rapat dan disimpan pada dua suhu berbeda. Parameter yang diukur meliputi tekstur kekerasan, $\mathrm{pH}, \mathrm{a}_{\mathrm{w}}$, dan warna dangke selama penyimpanan. Analisis berupa tekstur kekerasan, $\mathrm{pH}, \mathrm{a}_{\mathrm{w}}$, dan warna dilakukan setiap hari.

\section{Rendemen (Nugroho et al., 2018)}

Rendemen produk semakin tinggi, maka bahan yang digunakan lebih banyak sehingga dapat diketahui jumlah bahan yang dapat digunakan dalam penelitian. Rumus yang digunakan untuk menghitung rendemen adalah:

\section{Rendemen $=$}

$\frac{\text { berat akhir (berat padatan yang terbentuk) }}{\text { berat awal (berat susu yang digunakan) }} \times 100 \%$

Tekstur dangke (Rosenthal, 2010 dengan modifikasi)

Tekstur dangke dianalisis dengan metode texture profile analysis (TPA) menggunakan instrumen Texture Analyzer TA-XT 21. Sampel dangke dipotong dadu secara seragam ditekan dengan probe sebanyak 2 kali. Kecepatan probe yang digunakan 2 $\mathrm{mm} / \mathrm{s}$ dengan penekanan sampel sampai $30 \%$ dari tinggi awalnya. Parameter yang dilihat adalah nilai 
kekerasan yang muncul pada software texture analyzer TA-XT 21.

Nilai $\mathrm{pH}$, nilai $\mathrm{L}^{*}$ dan derajat putih (Cárdenas et al., 2018 dengan modifikasi; Kaemba et al., 2017; Maldonado et al., 2013)

Nilai $\mathrm{pH}$ dangke diukur menggunakan alat $\mathrm{pH}$ meter (Laqua PH1100 Horiba Instruments, Singapur) yang sudah dikalibrasi larutan bufer $\mathrm{pH} 7,0$ pada suhu $25^{\circ} \mathrm{C}$. Sebanyak $10 \mathrm{~g}$ sampel dangke dihaluskan dengan alat mortar, ditambahkan $20 \mathrm{~mL}$ akuades dan dihomogenkan. Sampel dimasukkan ke dalam wadah plastik, diaduk hingga rata dan dimasukkan probe $\mathrm{pH}$. Nilai $\mathrm{L}^{*}$ dangke diamati dengan chromameter CR-400 (Konica Minolta, Jepang) yang dinyatakan dengan nilai $L^{*}, a^{*}, b^{*}$ yang sebelumnya dikalibrasi dengan standar warna putih yang terdapat pada alat tersebut, sedangkan derajat putih dihitung dengan rumus:

$\left.W I=100\left[100-L^{\star}\right]^{2}+\left(a^{\star^{2}}+b^{\star^{2}}\right)\right]^{0,5}$

\section{Aktivitas air ( $\left.a_{w}\right)$ (Passot et al., 2012)}

Pengamatan $a_{w}$ dangke dilakukan menggunakan alat $a_{w}$ meter (Shibaura WA 360, Jepang). Sampel dangke dimasukkan ke dalam tempat sampel yang sebelumnya sudah dibersihkan lalu ditutup, kemudian ditunggu hingga $a_{w}$ konstan dan nilai $a_{w}$ dibaca dan dicatat. Perhatikan nilai temperatur sebagai faktor koreksi.

\section{Analisis statistik}

Data yang diperoleh dianalisis dengan software IBM SPSS statistic 25.0. tingkat signifikansi yang ditetapkan sebesar $\alpha=0,05$. Analisis dilanjutkan dengan uji Duncan jika diperoleh $P<0,05$ untuk melihat variabel yang berbeda. Masing-masing percobaan dilakukan sebanyak 2 kali ulangan.

\section{HASIL DAN PEMBAHASAN}

\section{Karakterisasi susu segar}

Susu segar yang digunakan memiliki kadar air $89,32 \%$, kadar abu $0,62 \%$, kadar protein $3,0 \%$, dan kadar lemak 2,50\% Hasil penelitian Mourad et al. (2014) menyatakan bahwa kadar air susu sapi segar adalah $87,2 \%$, kadar lemak $3,7 \%$, dan kadar abu $0,72 \%$. Adanya perbedaan karakteristik susu sapi pada penelitian diduga disebabkan banyak faktor, antara lain perbedaan kembang biak sapi, jenis sapi, kondisi peternakan (termasuk praktik manajemen dan komposisi pakan), perbedaan musim dan letak geografis (Aliyu et al., 2019).

\section{Pengaruh enzim terhadap rendemen, tekstur dan intensitas rasa pahit dangke}

Penentuan konsentrasi enzim dilakukan pada beberapa konsentrasi dengan parameter tekstur, rendemen dan intensitas rasa pahit yang dihasilkan. Berdasarkan tekstur, rendemen dan intensitas rasa pahit yang dihasilkan, terpilih 3 konsentrasi enzim yang digunakan untuk penelitian berikutnya yaitu konsentrasi 1, 3, dan 5\%. Tabel 1 menunjukkan tekstur, rendemen dan intensitas rasa pahit dangke yang dihasilkan dari masing-masing konsentrasi penggunaan enzim papain komersial. Penampilan dangke yang dibuat dengan papain komersial disajikan pada Gambar 1. Pemilihan konsentrasi enzim papain komersial pada konsentrasi 1, 3, dan $5 \%$ karena pemberian enzim papain komersial dibawah $1 \%$ tidak menghasilkan curd yang kompak atau tekstur yang dihasilkan rapuh serta rendemen rendah. Hal ini diduga karena tidak terbentuknya struktur enzim yang stabil sehingga enzim tidak mampu menghidrolisis kasein pada susu yang berfungsi sebagai substrat karena jumlah enzim dan substrat tidak sesuai (Risnawati dan Cahyaningrum, 2013).

Tabel 1. Tekstur, rendemen dan intensitas rasa pahit beberapa konsentrasi enzim papain komersial

\begin{tabular}{|c|c|c|c|}
\hline \multirow{2}{*}{$\begin{array}{l}\text { Konsentrasi } \\
\text { Enzim } \\
\text { Papain } \\
\text { Komersial } \\
(\%)\end{array}$} & \multicolumn{3}{|c|}{ Parameter } \\
\hline & Tekstur & $\begin{array}{c}\text { Rendemen } \\
(\%)\end{array}$ & $\begin{array}{l}\text { Intensitas } \\
\text { Rasa Pahit }\end{array}$ \\
\hline 0,2 & * & - & Tidak pahit \\
\hline 0,4 & * & - & Tidak pahit \\
\hline 0,6 & ** & 14 & Tidak pahit \\
\hline 0,8 & ** & 18,44 & Tidak pahit \\
\hline 1 & Terbentuk & 18,06 & Tidak pahit \\
\hline 3 & Terbentuk & 16,95 & Tidak pahit \\
\hline 5 & Terbentuk & 17,74 & Agak pahit \\
\hline
\end{tabular}

Keterangan: ${ }^{*}=$ Tekstur tidak terbentuk; $;^{* *}=$ Tekstur terlalu lunak

Susu yang telah ditambahkan enzim selama pemanasan akan membentuk padatan atau curd yang disebut rendemen. Enzim papain komersial konsentrasi 0,2 dan 0,4\% tidak menghasilkan rendemen, sedangkan rendemen pada penambahan konsentrasi 0,$6 ; 0,8 ; 1 ; 3$; dan $5 \%$ berturut-turut 14,$00 ; 18,44 ; 18,06 ; 16,95$; dan $17,74 \%$. Pemberian enzim dengan konsentrasi rendah menyebabkan penggumpalan tidak sempurna karena aktivitas enzim tidak optimal, sedangkan pemberian enzim dengan konsentrasi tinggi juga memungkinan aktivitas enzim rendah karena substrat yang tersedia tidak mencukupi kebutuhan enzim untuk bekerja. 


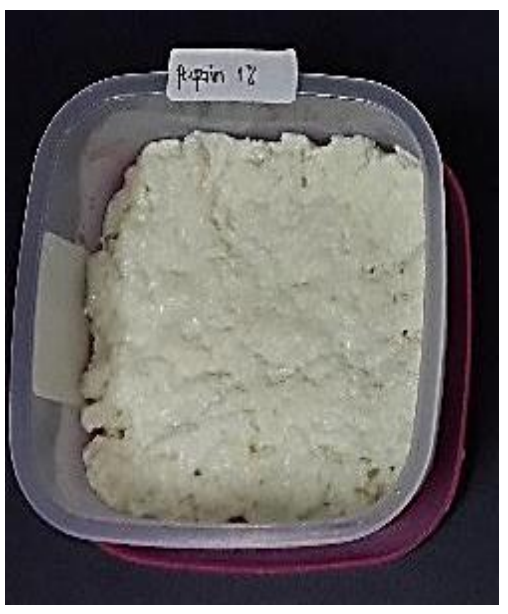

A

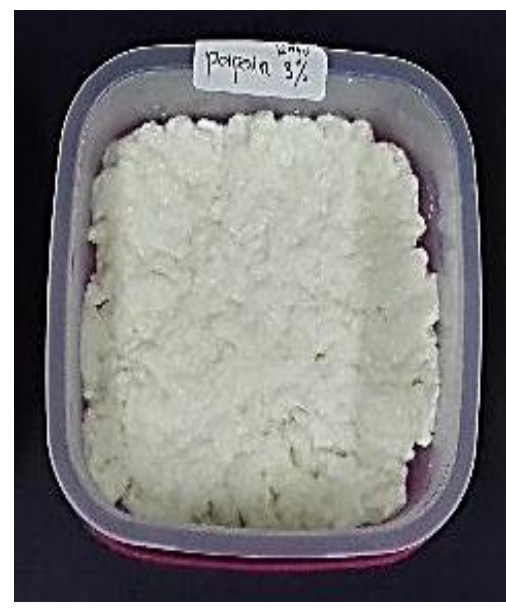

B

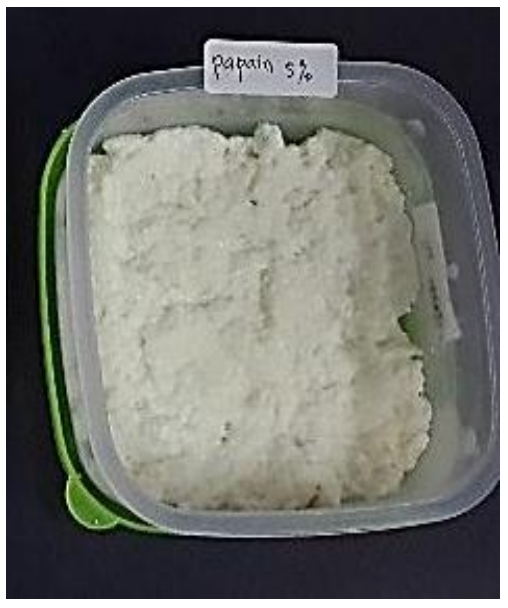

C

Gambar 1. Penampilan dangke yang dibuat dengan papain komersial 1\% (A), 3\% (B), $5 \%$ (C)

Penambahan enzim yang terlalu banyak juga berdampak pada rasa asin dangke dan sebagian berpendapat pahit yang kurang disukai. Penggunaan konsentrasi enzim papain komersial dibawah $1 \%$ tidak menghasilkan rasa asin dan pahit, namun tidak menghasilkan tekstur yang kompak, sementara penggunaan enzim papain komersial diatas 5\% menghasilkan rasa dangke yang asin sebab enzim papain komersial PAYA juga mengandung garam pada komposisinya.

Intensitas rasa pahit pada dangke papain komersial dinilai oleh 10 orang panelis dengan metode deskriptif. Panelis disediakan sampel dangke kemudian diminta untuk mencicipi dangke dan memberikan penilaian terhadap intensitas rasa pahit dari dangke.

Penelitian terkait keju menyebutkan bahwa perbedaan jumlah rendemen pada produk keju disebabkan oleh jumlah lemak yang tertahan pada produk. Dangke tergolong dalam keju segar. Sedikitnya jumlah lemak dan kasein yang hilang bersama whey dapat menghasilkan rendemen keju yang lebih tinggi (Widarta et al., 2016). Selain itu, perbedaan jumlah rendemen pada setiap konsentrasi enzim papain komersial disebabkan proses penekanan curd untuk mengurangi air. Proses penekanan pada dangke juga bertujuan untuk memisahkan curd dan whey agar curd yang dihasilkan lebih padat sehingga dangke memiliki struktur yang homogen (Budiman et al., 2017).

Hasil riset Mukhlisah et al. (2017) memanfaatkan getah pepaya selaku koagulan dalam pembuatan dangke konsentrasi 0,$2 ; 0,3$; dan $0,4 \%$ secara berturut-turut adalah 14,212; 15,79; dan 16,102\%. Hasil riset Fatma (2012) yang juga memanfaatkan getah pepaya selaku koagulan dengan konsentrasi 0,8 dan $0,9 \%$ menghasilkan rendemen 10,55 dan
10,54\%. Jika dibandingkan dengan kedua hasil riset sebelumnya yang menggunakan getah pepaya, hasil rendemen dangke pada penelitian ini terhitung lebih tinggi. Salah satu parameter penting dalam pengolahan keju adalah rendemen karena berhubungan dengan banyaknya jumlah keju yang diperoleh dan sekaligus menguntungkan secara ekonomi (Rana et al., 2017).

\section{Kekerasan}

Dangke yang diolah mengunakan susu sapi memiliki kadar air tinggi sekitar 49,3-62,4\% (Hatta et al., 2014) sehingga berpengaruh pada kekerasan yang dihasilkan. Tekstur yang terbentuk pada keju berhubungan dengan komposisi kimia pada tingkat mikro dan makrostruktur seperti kandungan protein dan lemak. Proses penggumpalan curd yang kurang sempurna dan dapat mempertahankan air lebih banyak menghasilkan tekstur produk yang kurang kompak atau lembek, sehingga tekstur keju segar rendah (Nugroho et al., 2018) Persentase air yang rendah pada suatu produk, menyebabkan tekstur bahan yang dihasilkan semakin keras (Engelen, 2018). Secara umum, tekstur yang dihasilkan oleh keju dipengaruhi oleh beberapa faktor, yaitu kadar air, kandungan lemak dan protein, garam dan $\mathrm{pH}$ (Sulistyo et al., 2018). Tabel 2 menunjukkan perubahan kekerasan dangke dengan enzim papain komersial selama penyimpanan suhu dingin.

Suhu termasuk indikator pokok yang bisa berdampak terhadap mutu keju selama penyimpanan. Pada suhu ruang dangke hanya bertahan beberapa jam sehingga tidak dilakukan analisis di hari ke-1 penyimpanan dan seterusnya, sehingga analisis hanya dilakukan pada dangke yang disimpan pada suhu dingin dengan suhu $\pm 4^{\circ} \mathrm{C}$. Dangke berada dalam kondisi baik selama 4 hari penyimpanan di 
suhu dingin dan mengalami kerusakan setelah lima hari penyimpanan. Kerusakan ditandai dengan keberadaan lendir pada permukaan dangke diduga akibat aktivitas mikroba, perubahan warna dan timbulnya aroma menyimpang. Jenis penyimpanan yang di-lakukan adalah ketika dangke sudah sampai di tangan konsumen, artinya produk yang sama diuji selama 4 hari.

Nilai kekerasan dangke menggunakan enzim papain komersial berkisar antara 153,85 sampai 1449,75 gf. Hasil uji ANOVA menunjukkan konsentrasi enzim papain komersial dan lama penyimpanan berpengaruh signifikan $(P<0,05)$ terhadap kekerasan dangke. Hasil uji Duncan ( $\alpha=5 \%$ ), dangke dengan penambahan konsentrasi enzim papain komersial $1 \%$ berbeda dengan penambahan konsnetrasi 3 dan $5 \%$. Penyimpanan dangke pada hari ke-0 berbeda signifikan dengan dangke yang disimpan pada hari ke-1, ke-2, ke-3 dan ke-4.

Tabel 2 memperlihatkan bahwa dangke P1, P3 dan P5 hari ke-0 memiliki tingkat kekerasan relatif sama dan sama-sama mengalami peningkatan pada hari ke-4 penyimpanan. Fluktuasi kekerasan terjadi selama penyimpanan. Dangke P1 mengalami pfeningkatan kekerasan paling tinggi diantara dangke lainnya. Seiring bertambahnya waktu penyimpanan, kekerasan dangke cenderung mengalami peningkatan pada masing-masing konsentrasi enzim. Salah satu faktor yang mempengaruhi kekerasan keju adalah $\mathrm{pH}$. Dangke P1 memiliki $\mathrm{pH}$ yang lebih rendah daripada $\mathrm{P} 3$ dan $\mathrm{P} 5$ dan memiliki kekerasan lebih tinggi pada hari ke-4 dibanding P3 dan P5. Selain itu, peningkatan kekerasan P1 diduga karena terjadi penurunan kadar air yang lebih cepat selama penyimpanan di suhu dingin karena proses sineresis.

\section{Nilai pH}

Kadar keasaman suatu produk pangan dapat ditentukan dengan pengukuran nilai $\mathrm{pH}$. Pada penelitian ini, $\mathrm{pH}$ susu yang digunakan adalah 6,93 sedangkan $\mathrm{pH}$ dari enzim papain komersial adalah 7,1. Tabel 2 menunjukkan perubahan $\mathrm{pH}$ dangke dengan enzim papain komersial selama penyimpanan suhu dingin.

Tabel 2. Sifat fisik (Kekerasan, $\mathrm{pH}, \mathrm{a}_{\mathrm{w}}$, kecerahan dan derajat putih) dangke menggunakan enzim papain komersial selama penyimpanan

\begin{tabular}{|c|c|c|c|c|}
\hline \multirow{2}{*}{$\begin{array}{c}\text { Parameter } \\
\text { Pengamatan }\end{array}$} & \multirow{2}{*}{$\begin{array}{c}\text { Periode } \\
\text { Penyimpanan } \\
\text { (Hari) }\end{array}$} & \multicolumn{3}{|c|}{ Konsentrasi Enzim Papain Komersial (\%) } \\
\hline & & 1 & 3 & 5 \\
\hline \multirow[t]{5}{*}{ Kekerasan (gf) } & 0 & $298,35 \pm 3,18^{\mathrm{aA}}$ & $246,40 \pm 48,65^{\mathrm{bA}}$ & $153,85 \pm 15,20^{\mathrm{DA}}$ \\
\hline & 1 & $595,75 \pm 186,75^{\mathrm{aBC}}$ & $683,50 \pm 106,77^{\mathrm{bBC}}$ & $762,00 \pm 23,48^{\mathrm{bBC}}$ \\
\hline & 2 & $809,85 \pm 192,12^{\text {ав }}$ & $366,55 \pm 24,68^{\mathrm{bB}}$ & $459,10 \pm 34,08^{\mathrm{bB}}$ \\
\hline & 3 & $722,10 \pm 112,01^{\text {авс }}$ & $862,30 \pm 236,32^{\mathrm{bBC}}$ & $556,60 \pm 0,00^{\mathrm{bBC}}$ \\
\hline & 4 & $1449,75 \pm 409,20^{\mathrm{ac}}$ & $626,35 \pm 190,99^{\mathrm{bc}}$ & $428,75 \pm 26,38^{\mathrm{bc}}$ \\
\hline \multirow[t]{5}{*}{$\mathrm{pH}$} & 0 & $6,15 \pm 0,13^{\mathrm{aAB}}$ & $6,45 \pm 0,05^{\mathrm{aAB}}$ & $6,77 \pm 0,04^{\mathrm{aAB}}$ \\
\hline & 1 & $6,30 \pm 0,08^{\mathrm{aB}}$ & $7,00 \pm 0,10^{\mathrm{aB}}$ & $6,40 \pm 0,22^{\mathrm{aB}}$ \\
\hline & 2 & $7,24 \pm 0,46^{\mathrm{ab}}$ & $6,13 \pm 0,07^{\text {ab }}$ & $6,39 \pm 0,05^{\text {ав }}$ \\
\hline & 3 & $7,13 \pm 0,57^{\text {ab }}$ & $6,21 \pm 0,13^{\mathrm{ab}}$ & $6,34 \pm 0,02^{\mathrm{ab}}$ \\
\hline & 4 & $5,86 \pm 0,13^{\mathrm{aA}}$ & $6,72 \pm 0,02^{\mathrm{aA}}$ & $6,07 \pm 0,03^{\mathrm{aA}}$ \\
\hline \multirow[t]{5}{*}{$a_{w}$} & 0 & $0,942 \pm 0,02^{\mathrm{abA}}$ & $0,957 \pm 0,00^{\mathrm{bA}}$ & $0,944 \pm 0,01^{a A}$ \\
\hline & 1 & $0,953 \pm 0,00^{\mathrm{abA}}$ & $0,947 \pm 0,01^{\mathrm{bA}}$ & $0,938 \pm 0,00^{\mathrm{aA}}$ \\
\hline & 2 & $0,923 \pm 0,00^{\mathrm{abb}}$ & $0,929 \pm 0,00^{\mathrm{bB}}$ & $0,930 \pm 0,00^{\text {ав }}$ \\
\hline & 3 & $0,936 \pm 0,01^{\mathrm{abb}}$ & $0,937 \pm 0,01^{\mathrm{bB}}$ & $0.914 \pm 0.01^{\text {ав }}$ \\
\hline & 4 & $0,934 \pm 0,00^{\mathrm{abAB}}$ & $0,952 \pm 0,02^{\mathrm{bAB}}$ & $0,924 \pm 0,01^{\mathrm{aAB}}$ \\
\hline \multirow[t]{5}{*}{ Nilai L* } & 0 & $87,11 \pm 2,63^{\mathrm{aA}}$ & $90,84 \pm 0,11^{a A}$ & $89,34 \pm 0,54^{\mathrm{aA}}$ \\
\hline & 1 & $87,16 \pm 0,85^{\text {ав }}$ & $85,65 \pm 0,88^{\mathrm{ab}}$ & $87,18 \pm 0,03^{\text {ав }}$ \\
\hline & 2 & $87,56 \pm 0,62^{\text {ав }}$ & $85,96 \pm 0,37^{\mathrm{ab}}$ & $86,41 \pm 0,34^{\mathrm{ab}}$ \\
\hline & 3 & $86,77 \pm 0,51^{\text {ав }}$ & $85,24 \pm 0,66^{\mathrm{ab}}$ & $86,10 \pm 0,28^{\mathrm{ab}}$ \\
\hline & 4 & $87,19 \pm 1,29^{\text {ав }}$ & $85,53 \pm 0,28^{\mathrm{ab}}$ & $86,31 \pm 0,85^{\mathrm{ab}}$ \\
\hline \multirow[t]{5}{*}{ Derajat Putih } & 0 & $80,766 \pm 1,82^{\mathrm{aA}}$ & $84,148 \pm 0,25^{\mathrm{DA}}$ & $83,091 \pm 0,07^{\mathrm{abA}}$ \\
\hline & 1 & $83,189 \pm 0,66^{\text {аАВ }}$ & $81,513 \pm 0,61^{\text {БАВ }}$ & $82,462 \pm 0,07^{\mathrm{abAB}}$ \\
\hline & 2 & $83,227 \pm 0,41^{\text {aAB }}$ & $81,387 \pm 0,19^{\mathrm{bAB}}$ & $81,794 \pm 0,13^{\mathrm{abAB}}$ \\
\hline & 3 & $82,617 \pm 0,19^{\mathrm{aB}}$ & $81,044 \pm 0,01^{\mathrm{bB}}$ & $81,702 \pm 0,44^{\mathrm{abB}}$ \\
\hline & 4 & $82,923 \pm 0,72^{\text {ав }}$ & $80,795 \pm 0,52^{\text {bь }}$ & $81,698 \pm 0,27^{\text {abs }}$ \\
\hline
\end{tabular}

Keterangan: Nilai merupakan rata-rata \pm standar deviasi $(n=2)$; Pada setiap parameter angka-angka pada baris yang sama diikuti oleh huruf kecil yang berbeda, berbeda nyata $(P<0,05$, duncan); Angka-angka pada kolom yang sama diikuti oleh huruf kapital yang berbeda, berbeda nyata $(P<0,05$, duncan) 
Nilai pH dangke dengan enzim papain komersial selama penyimpanan suhu dingin berkisar antara 6,19-7,24. Hasil uji ANOVA menunjukkan konsentrasi enzim papain komersial tidak berpengaruh nyata $(P>0,05)$ terhadap $\mathrm{pH}$ dangke, sedangkan lama penyimpanan berpengaruh nyata $(P<0,05)$ terhadap $\mathrm{pH}$ dangke. Hasil uji Duncan $(\alpha=$ $5 \%$ ), dangke yang disimpan pada hari ke-0 dan ke-4 berbeda nyata dengan dangke yang disimpan pada hari ke-1, ke-2, ke-3, dan ke-4.

Pada Tabel 2 terlihat bahwa dangke P1, P3 dan P5 pada hari ke-0 dan hari ke-4 memiliki nilai $\mathrm{pH}$ relatif sama. Fluktuasi $\mathrm{pH}$ terjadi pada hari ke-2 dan ke-3 penyimpanan dan setelah itu mengalami penurunan pada hari ke-4 penyimpanan. Hasil penelitian Hatta et al. (2014) yang meneliti dangke menggunakan susu sapi dan getah pepaya memperoleh rata-rata $\mathrm{pH}$ dangke yang diolah dengan susu sapi memiliki $\mathrm{pH} 6,4$. Berbeda dengan hasil penelitian Sulmiyati dan Said (2018) yang meneliti dangke yang menggunakan crude papain dan susu kerbau memperoleh $\mathrm{pH}$ dangke sekitar 6,92 dan 6,96. Hasil penelitian Malaka (2015) yang meneliti dangke menggunakan getah pepaya dan susu sapi memperoleh nilai $\mathrm{pH}$ dangke sekitar $6,0-6,71$. Hal ini menunjukkan bahwa dangke merupakan produk pangan yang cepat mengalami kerusakan sebab memiliki rata-rata nilai $\mathrm{pH}$ yang mendekati nilai $\mathrm{pH}$ netral. Seiring bertambahnya waktu penyimpanan pada suhu dingin, terjadi penurunan nilai $\mathrm{pH}$. Hasil penelitian Setyawardani et al. (2019) menyatakan bahwa waktu penyimpanan memengaruhi nilai $\mathrm{pH}$ keju. Semakin lama keju disimpan pada suhu freezer dan refrigerator (LG GN-B392RLC, Indonesia) maka dihasilkan nilai $\mathrm{pH}$ yang semakin kecil.

\section{Aktivitas air $\left(\mathbf{a}_{\mathrm{w}}\right)$}

Keju segar seperti cream cheese dan cottage mempunyai persentase air dan kelembaban yang lebih besar, sehingga memiliki umur simpan yang relatif lebih pendek (El-Nimr et al., 2010). Keju memiliki $a_{w}$ berkisar dari 0,89 hingga 0,99 sehingga berpotensi terkontaminasi bakteri. Beberapa faktor yang mempengaruhi penurunan $a_{w}$ selama proses pematangan keju diantaranya garam, kehilangan kadar air (Salguero et al., 1986). Tabel 2 menunjukkan perubahan $a_{w}$ dangke dengan enzim papain komersial selama penyimpanan suhu dingin.

Nilai $a_{w}$ dangke dengan enzim papain komersial selama penyimpanan suhu dingin berkisar antara 0,91-0,95. Hasil uji ANOVA menujukkan konsentrasi enzim papain komersial dan lama penyimpanan berpengaruh nyata $(P<0,05)$ terhadap $a_{w}$ dangke. Hasil uji Duncan $(\alpha=5 \%)$ menunjukkan bahwa penyimpanan dangke P3 dan P5 berbeda, sedangkan penyimpanan pada hari ke-0 dan hari ke- 1 tidak berbeda nyata, namun berbeda pada hari ke-2, ke-3 dan ke-4 penyimpanan. Dangke dengan enzim P1, P3 dan P5 memiliki nilai $a_{w}$ yang relatif sama pada hari ke-0 dan hari ke-4 penyimpanan. Fluktuasi nilai $a_{w}$ terlihat selama rentang waktu penyimpanan.

Hasil penelitian ini, rata-rata nilai $a_{w}$ yang diperoleh pada hari ke-0 adalah 0,947 dan pada hari ke-4 penyimpanan diperoleh $a_{w}$ sebesar 0,937 , terlihat terdapat penurunan $a_{w}$ selama penyimpanan dangke suhu dingin. Penurunan nilai $a_{w}$ selama penyimpanan diduga karena adanya garam dalam produk. Enzim dalam susu dan starter secara bertahap menghidrolisis konstituen keju dan menurunkan aktivitas air. Perubahan ini relatif kecil dalam fresh cheese dan soft cheese tetapi sangat jelas dalam hard cheese dan semi-hard cheese. Keberadaan garam dalam produk mengurangi aktivitas air (Arboatti et al., 2014). Air yang terikat matriks curd akan mengikat gugus karboksil dan amino pada asam amino yang terbentuk (Arini, 2016). Hasil ini sama dengan hasil riset El-Nimr et al. (2010) melakukan penyimpanan keju segar Gouda selama 60 hari dangan nilai $a_{w} 0,93$ pada awal penyimpanan dan 0,51 pada akhir penyimpanan. Hasil riset Mukhlisah et al. (2017) yang meneliti dangke menggunakan getah pepaya konsentrasi 0,$2 ; 0,3$; dan $0,5 \%$ memperoleh nilai $a_{w}$ masing-masing 0,874 ; 0,875 ; dan 0,872 .

\section{Nilai $L^{*}$}

Kecerahan cenderung memiliki warna akrobatik putih, abu-abu dan hitam. Kecerahan dilambangkan dengan notasi Nilai $L^{*}$ dengan nilai antara $0-100$ dari warna hitam hingga putih. Secara visual, warna dangke secara umum terlihat berwarna putih. Tabel 2 menunjukkan perubahan kecerahan dangke dengan enzim papain komersial selama penyimpanan suhu dingin.

Nilai kecerahan dangke dengan enzim papain komersial selama penyimpanan berkisar antara 85,24 sampai 90,84. Hasil uji ANOVA menunjukkan bahwa konsentrasi enzim papain komersial tidak berpengaruh nyata $(P>0,05)$ terhadap kecerahan dangke, sedangkan lama penyimpanan berpengaruh nyata $(P<0,05)$ terhadap kecerahan dangke papain komersial. Hasil uji Duncan ( $\alpha=5 \%)$, menunjukkan bahwa kecerahan dangke hari ke-0 berbeda nyata dengan dangke yang disimpan pada hari ke-1, ke-2, ke-3, dan ke-4.

Tabel 2 menujukkan bahwa nilai kecerahan P1, P3 dan P5 relatif sama pada hari ke-0 dan cenderung mengalami penurunan selama penyimpanan. Laju penurunan tingkat kecerahan pun relatif sama pada semua konsentrasi dangke papain komersial. Seiring bertambahnya periode penyimpanan, kecerahan dangke juga semakin menurun. Hasil ini sejalan dengan hasil penelitian El-Nimr et al. (2010) yang meneliti keju gouda selama pemeraman memperlihatkan nilai kecerahan yang 
menurun selama 60 hari pemeraman. Hasil yang sama juga didapatkan dari penelitian Nedomová et al. (2017) yang meneliti keju yang diperam selama 60 hari mendapatkan nilai kecerahan yang menurun selama pemeraman. Begitu juga dengan hasil penelitian Sant'Ana et al. (2013) yang melakukan penelitian pada keju segar minas diperoleh nilai kecerahan yang semakin menurun seiring bertambahnya waktu penyimpanan.

\section{Derajat putih}

Kemampuan bahan untuk memantulkan cahaya yang mengenai permukaan bahan ditunjukkan dengan derajat putih (Iswari et al., 2017). Derajat putih dangke dengan enzim papain komersial selama penyimpanan berkisar 80,766-84,148. Hasil uji ANOVA menunjukkan bahwa konsentrasi enzim papain komersial berpengaruh nyata $(P>0,05)$ terhadap derajat putih dangke, sedangkan lama penyimpanan tidak berpengaruh nyata $(P<0,05)$ terhadap derajat putih dangke yang dihasil-kan. Hasil uji Duncan $(\alpha=5 \%)$, menunjukkan bahwa derajat putih dangke P1 dan P5 tidak berbeda signifikan, namun keduanya berbeda signifikan dengan P3. Tabel 2 menunjukkan perubahan derajat putih dangke papain komersial selama penyimpanan suhu dingin.

Kecenderungan derajat putih dangke $\mathrm{P} 1, \mathrm{P} 3$ dan P5 selama penyimpanan dan relatif sama sampai akhir periode penyimpanan. Penurunan mulai terjadi pada hari ke-3 penyimpanan. Penurunan derajat putih dangke selama periode penyimpanan diduga disebabkan karena adanya penurunan $\mathrm{pH}$ dan penurunan kandungan lemak pada ketiga dangke selama penyimpanan. Hasil ini sejalan dengan hasil penelitian Maldonado et al. (2013) yang meneliti pasta filata keju talita memperoleh nilai derajat putih tertinggi pada $\mathrm{pH} 5,7$ yaitu 84,59 dan nilai derajat putih terendah pada $\mathrm{pH} 5,2$ yaitu 77,5 . Penurunan keputihan selama penyimpanan diduga juga terkait dengan peningkatan hidrasi protein yang mencerminkan penurunan jumlah tetesan kelembaban bebas sehingga menurunkan derajat hamburan cahaya (Rahimi et al., 2007).

\section{KESIMPULAN}

Berdasarkan hasil penelitian dapat disimpulkan bahwa konsentrasi enzim papain komersial yang tepat digunakan dalam pembuatan dangke adalah $1 \%(\mathrm{w} / \mathrm{v})$ yang menghasilkan dangke dengan rendemen $18 \%$, intensitas rasa tidak pahit. Dangke dengan enzim papain komersial bertahan selama 4 hari pada penyimpanan suhu dingin. Kekerasan dan $\mathrm{pH}$ dangke dengan enzim papain komersial mulai meningkat pada hari ke-1 penyimpanan, kecuali dangke konsentrasi 5\%, pH menurun pada hari ke-1 penyimpanan, aktivitas air $\left(a_{w}\right)$ menurun pada hari ke-2 penyimpanan, nilai $L^{*}$ dangke menurun pada hari ke-1 penyimpanan, sementara derajat putih mulai menurun pada hari ke-3 penyimpanan.

\section{DAFTAR PUSTAKA}

[AOAC] Association of Official Analytical Chemist. 2012. Official method of analysis of ahe Association of official analytical of chemist, $19^{\text {th }}$ Edition Volume II. The Association of Official Analytical Chemist, Inc, Gaithersburg (US).

Aliyu Y, Abdullahi IO, Whong CMZ, Anumiri CE, Bwala JD, Esimi JS. 2019. The proximate composition of fresh and fermented milk in parts of Nasarawa State, Nigeria. Asian Food Sci J 10: 1-12. DOI: 10.9734/afsj/2019/v10i43 0047.

Arboatti AS, Olivares ML, Sabbag NG, Costa SC, Zorrilla SE, Sihufe GA. 2014. The influence of sodium chloride reduction on physicochemical, biochemical, rheological and sensory characteristics of mozzarella cheese. Dairy Sci Technol 94: 373-386. DOI 10.1007/s13594014-0169-2.

Arini N. 2016. Upaya Peningkatan Kualitas Sensori dan Preservasi Dangke Susu Sapi dengan Penambahan Lemak Susu dan Supernatan Lactobacillus plantarum (Lactococcus lactis fncc 0086) [Disertasi]. Bogor: Fakultas Kedokteran Hewan, Institut Pertanian Bogor.

Cárdenas N, Calzada J, Peirotén A, Jiménez E, Escudero $R$, Rodríguez JM, Medina $M$, Fernández L. 2014. Development of a potential probiotic fresh cheese using two Lactobacillus salivarius strains isolated from human milk. Biomed Res Int 2014: 1-12. DOI: 10.1155/2014/ 801918.

El-Nimr AA, Eissa HA, El-Abd MM, Mehriz AA, Abbas HM, Bayoumi HM. 2010. Water activity, color characteristics and sensory properties of egyptian gouda cheese during ripening. J Am Sci 6: 447-453.

Engelen A. 2018. Analisis kekerasan, kadar air, warna dan sifat sensori pada pembuatan keripik daun kelor. J Agritech Sci 2: 10-15.

Evert-Arriagada K, Hernández-Herrero MM, Gallardo-Chacón JJ, Juan B, Trujillo AJ. 2013. Effect of high pressure processing on volatile compound profile of a starter-free fresh cheese. Innov Food Sci Emerg Tech 19: 73-78. DOI: 10.1016/j.ifset.2013.04.001. 
Fatma, Soeparno, Nurliyani, Hidayat C, Taufik M. 2012. Karakteristik whey limbah dangke dan potensinya sebagai produk minuman dengan menggunakan Lactobacillus acidophilus FNCC 0051. Agritech 32: 352-361.

González ML, Sánchez HC, Franco FMJ, Güemes VN, Soto SS. 2018. Physical, chemical and texture characteristics of Aro cheese. Food Res 2: 61-67. DOI: 10.26656/fr.2017.2(1).211.

Hatta W, Sudarwanto MB, Sudirman I, Malaka R. 2013. Survei potensi dangke susu sapi sebagai alternatif dangke susu kerbau di Kabupaten Enrekang, Sulawesi Selatan. JITP 3: 40-50.

Hatta W, Sudarwanto MB, Sudirman I, Malaka R. 2014. Survei karakteristik pengolahan dan kualitas produk dangke susu sapi di Kabupaten Enrekang, Sulawesi Selatan. JITP 3: 154-161.

Hutagalung TM, Yelnetty A, Tamasoleng M, Ponto JHW. 2017. Penggunaan enzim rennet dan bakteri Lactobacillus plantarum YN 1.3 terhadap sifat sensoris keju. J Zootek 37: 286293. DOI: 10.35792/zot.37.2.2017.16068.

Iswari K, Astuti HF, Srimaryati. 2017. Pengaruh lama fermentasi terhadap mutu tepung cassava termodifikasi.. Prosiding Seminar Nasional 2016, Membangun Pertanian Modern Dan Inovatif Berkelanjutan dalam Rangka Mendukung MEA, 1250-1257, 31-1 Mei-Jun 2016, Lemlit Universitas Jambi.

Kaemba A, Suryanto E, Mamuaja CF. 2017. Aktivitas antioksidan beras analog dari sagu baruk (Arenga microcarpha) dan ubi jalar ungu (Ipomea batatas L. poiret). Chem Prog 10: 6268.

Malaka R, Baco S, Prahesti KI. 2015. Karakteristik dan mekanisme gelatinasi curd dangke melalui analisis fisiko kimia dan mikrostruktur. JITP 4: 56-62.

Maldonado R, Melendez B, Arispe I, Boeneke C, Torrico D, Prinyawiwatkul W. 2013. Effect of $\mathrm{pH}$ on technological parameters and physicochemical and texture characteristics of the pasta filata cheese Telita. J Dairy Sci 96: 7414-7426. DOI: 10.3168/jds.2013-6887.

Mourad G, Bettache G, Samir M. 2014. Composition and nutritional value of raw milk. Issues Biol Sci Pharm Res 2: 115-122. DOI: 10.15739/ibspr. 005.

Mukhlisah AN, Arief II, Taufik E. 2017. Physical, microbial, and chemical qualities of Dangke produced by different temperatures and papain concentrations. Media Peternakan 40: 63-70. DOI: 10.5398/medpet.2017.40.1.63.

Nedomová S, Kilián L, Pytel R, Kumbár V. 2017. Effect of ripening time on colour and texture properties in cheese. Potravinarstvo Slovak J Food Sci 11: 296-301. DOI: 10.5219/744.

Nugroho P, Dwiloka B, Rizqiati H. 2018. Rendemen, nilai $\mathrm{pH}$, tekstur, dan aktivitas antioksidan keju segar dengan bahan pengasam ekstrak bunga rosella unggu (Hibiscus sabdariffa L.). J Teknol Pangan 2: 33-39.

Passot S, Cenard S, Douanial, Tréléal C, Fonseca F. 2012. Critical water activity and amorphous state for optimal preservation of lyophilized lactic acid bacteria. Food Chem 132: 16991705. DOI: 10.1016/j.foodchem.2011.06.012.

Rahimi J, Khosrowshahi A, Madadlou A, Aziznia S. 2007. Texture of low-fat iranian white cheese as influenced by gum tragacanth as a fat replacer. J Dairy Sci 90: 4058-4070. DOI: 10. 3168/jds.2007-0121.

Rana MS, Hoque MR, Rahman MO, Habib R, Siddiki MSR. 2017. Papaya (Carica papaya) latex an alternative to rennet for cottage cheese preparation. J Adv Vet Anim Res 4: 249-254. DOI: 10.5455/javar.2017.d218.

Risnawati M, Cahyaningrum SE. 2013. Pengaruh penambahan ion logam $\mathrm{Ca}_{2+}$ terhadap aktivitas enzim papain. Unesa J Chem 2: 76-83.

Rosenthal AJ. 2010. Texture profile analysis-How important are the parameters?. J Texture Stud 41: 672-684. DOI: 10.1111/j.1745-4603.2010. 00248.x

Sant'Ana AMS, Bezerril FF, Madruga MS, Batista ASM, Magnani m, Souza L, Queiroga RCRE. 2013. Nutritional and sensory characteristics of Minas fresh cheese made with goat milk, cow milk, or a mixture of both. J Dairy Sci 96: 74427453. DOI: 10.3168/jds.2013-6915.

Setyawardani T, Sumarmono J, Widayaka K. 2019. Effect of cold and frozen temperatures on artisanal goat cheese containing probiotic lactic acid bacteria isolates (Lactobacillus plantarum TW14 and Lactobacillus rhamnosus TW2). Vet World 12: 409-417. DOI: 10.14202/vetworld. 2019.409-417.

Sulistyo B, Chairunnisa H, Wulandari E. 2018. Pengaruh penggunaan kombinasi enzim papain dan jus lemon sebagai koagulan terhadap kadar air, berat rendemen, dan nilai kesukaan fresh cheese. J Ilmu Ternak 18: 9-16. DOI: 10. 24198/jit.v18i1.15299. 
Sulmiyati S, Said NS. 2018. Karakteristik dangke susu kerbau dengan penambahan crude papain kering. Agritech 38: 345-352. DOI: 10.22146/ agritech.24331.

Sumarlan SH, Wibisono Y, Hawa LC, Nurwindi LL. 2017. Pengaruh penambahan enzim papain komersial dalam pembuatan hidrolisat protein dari limbah cair surimi. J Keteknikan Pertanian Tropis Biosistem 5: 56-65.
Suryani T, Niswah F. 2015. Pemanfaatan susu kambing etawa dan kedelai sebagai bahan dasar dangke (keju khas Indonesia) dengan koagulan ekstrak jeruk nipis. Bioeksperimen 1: 45-52.

Widarta IWR, Wisaniyasa NW Prayekti H. 2016. Pengaruh penambahan ekstrak belimbing wuluh (Averrhoa bilimbi L.) terhadap karakteristik fisikokimia keju mozzarella. J Ilmiah Teknol Pertanian Agrotechno 1: 37-45. 